\title{
The Ulva spp. Conundrum: What Does the Ecophysiology of Southern Atlantic Specimens Tell Us?
}

\author{
Vinícius Peruzzi Oliveira $\mathbb{D}^{\mathrm{D}},{ }^{1}$ Barbara Lage Ignacio, ${ }^{2}$ Nuno Tavares Martins, ${ }^{3}$ \\ Leticia Dobler, ${ }^{4}$ and Alex Enrich-Prast ${ }^{5,6}$ \\ ${ }^{1}$ Universidade Federal do Rio de Janeiro (UFRJ), Departamento de Biologia Marinha, Brazil \\ ${ }^{2}$ Universidade Federal de São Paulo (UNIFESP), Departamento de Ciências do Mar, Brazil \\ ${ }^{3}$ Universidade de São Paulo (USP), Instituto de Biociências, Brazil \\ ${ }^{4}$ Universidade Federal do Rio de Janeiro (UFRJ), Instituto de Química, Brazil \\ ${ }^{5}$ Universidade Federal do Rio de Janeiro (UFRJ), Departamento de Botânica, Brazil \\ ${ }^{6}$ Linköping University, Department of Thematic Studies, Sweden \\ Correspondence should be addressed to Vinícius Peruzzi Oliveira; viniciusperuzzi@gmail.com
}

Received 20 September 2018; Revised 5 December 2018; Accepted 7 February 2019; Published 3 March 2019

Academic Editor: Shamsul Hayat

Copyright (C) 2019 Vinícius Peruzzi Oliveira et al. This is an open access article distributed under the Creative Commons Attribution License, which permits unrestricted use, distribution, and reproduction in any medium, provided the original work is properly cited.

Species of the genus Ulva are common in anthropogenically disturbed areas and have been reported as the cause of green tides in many areas of the world. In addition, they rank among the main marine groups used in a wide range of commercial applications. By displaying few distinctive morphological characters, some taxonomical identifications are difficult and the genus is under a conundrum. Our aims were to provide ecophysiological information about three Ulva species in response to abiotic factors and to evaluate the proposal of ecophysiological information and the chlorophyll- $a$ fluorescence technique as auxiliary tool to resolve the long-standing taxonomic confusion. We hypothesize that three cooccurring specimens (U. fasciata Delile, U. lactuca Linnaeus, and U. rigida C. Agardh) have different ecophysiological responses (as measured by the effective quantum yield of photosystem II by pulse amplitude modulated fluorometers) under manipulated conditions of temperature and nutrient concentration. Ulva lactuca and $U$. rigida showed different photosynthetic efficiencies related to temperature, whereas no difference was recorded for $U$. fasciata individuals. These results provide a reasonable explanation for the variability in spatial and temporal abundance of these species of Ulva on rocky shores. We proposed the use of ecophysiological information by chlorophyll-a fluorescence as an auxiliary tool to corroborate the taxonomic distinction of Ulva species. We reinforce the statement of $U$. fasciata and U. lactuca as distinct valid species.

\section{Introduction}

The genus Ulva (Chlorophyta) comprises cosmopolitan macroalgae that inhabit a gradient from freshwater to fully saline shallow environments [1]. Species of this genus rank among the first species to be established in disturbed environments because of their morpho-physiological features, that allow tolerance to wide range of environmental conditions [2-4]. Some species of Ulva have been emphasized due to reports as the cause of green tides in many parts of the world [5]. Additionally, numerous studies have also demonstrated functions in bioremediation of eutrophic environments and uses of their biomass and carbohydrate content in the pharmaceutical, food, and energy chain [6-8].

Ongoing advances in molecular biology have driven taxonomic revisions, and morphological features have lost credibility as the primary species delimitation criterion for many groups (see [9] for algae). Ulva is one of the genera involved in a taxonomic conundrum that entangles morphological or molecular data for species identification, mainly involving distinction around U. lactuca and U. fasciata (see [1, 10-13]). In spite of the undeniable contribution of molecular methods to taxonomy (see [14-17]), there is no easy way to determine the accurate match between the GenBank sequences and the 
morphological characterization of most studies, which has led to uncertainty and sometimes to misinterpretation (see $[1,11])$.

In the latter context, physiological markers that are associated with the photosynthesis process may be especially helpful. Photosynthetic organisms adjust the operation of their photosynthetic apparatus to optimize or preserve metabolism under stress, which can be detected by chlorophyll- $a$ fluorescence variation $[18,19]$. In this case, the evaluation of the effective quantum yield of PSII by pulse amplitude modulated (PAM) fluorometers has been proposed as an attractive measure of the ecophysiological condition [20-24]. This technique is notable for performing a nonintrusive real-time analysis under both laboratory and field conditions [25] and has been applied for establishing the differences among morphotypes of macroalgae [26].

Under this background, the aim of this study was to provide comparative ecophysiological information about three cooccurring species of Ulva in the Southwestern Atlantic (Ulva rigida C. Agardh, Ulva lactuca Linnaeus, and Ulva fasciata Delile) that were morphologically identified. We assessed the effect of temperature and nutrient variation on the photosynthetic efficiency (by chlorophyll- $a$ fluorescence measurements) of the three species. The general tested hypothesis was that species would have different responses to both of the tested factors. We subsequently expect to provide useful information for using PAM fluorometry of Ulva as a reliable tool for ecophysiological assessment and for the taxonomic debate about Ulva.

\section{Material and Methods}

2.1. Sampling. The three species of Ulva (U. fasciata, U. lactuca, and U. rigida) were collected during summer (January $2010)$ in the intertidal zone at Prainha Beach $\left(22^{\circ} 57^{\prime} \mathrm{S}, 042^{\circ}\right.$ $\left.01^{\prime} \mathrm{W}\right)$, Rio de Janeiro, Brazil. Immediately, the epibionts were removed, and the macroalgae were kept in cool boxes with local seawater $\left(\sim 30 \mu \mathrm{M} \mathrm{NO}_{3}, 3 \mu \mathrm{M} \mathrm{PO}_{4}, 19^{\circ} \mathrm{C}\right.$, and $\left.35 \mathrm{PSU}\right)$ filtered through $10-\mu \mathrm{m}$ mesh filters.

2.2. The Species. The morphological taxonomy of the three studied species ( $U$. fasciata, U. lactuca, and $U$. rigida) was based on botanical descriptions and inventories that considered in-depth confrontation among the species descriptions and the Southwestern Atlantic specimens [27-30]. Individuals were prepared as herbarium vouchers and deposited in the herbarium of the Universidade Federal do Rio de Janeiro/UFRJ (under the accession numbers RFA 42441; 42442; 42443).

2.3. Experimental Design. All the individuals were maintained in Erlenmeyer flasks in a proportion of $1 \mathrm{~g}$ of fresh mass $\mathrm{L}^{-1}$ pasteurized oligotrophic ocean water with added trace nutrients $\left(<1 \mu \mathrm{M} \mathrm{NH}_{4} ;<1 \mu \mathrm{M} \mathrm{NO}_{3} ;<2 \mu \mathrm{M} \mathrm{NO}_{2} ;<1\right.$ $\mu \mathrm{M} \mathrm{PO}_{4}$ ), at $20^{\circ} \mathrm{C}$ and $200 \mu \mathrm{mol}$ photons $\mathrm{m}^{-2} \mathrm{~s}^{-1}$ (PAR, photosynthetically active radiation) for 15 days. This phase was established to set all the macroalgae to the same nutritional and physiological state before the manipulative experiment.
This PAR was chosen because it is an intermediate value in relation to the saturation parameter that is found in the P-I curves (100-400 photons $\mathrm{m}^{-2} \mathrm{~s}^{-1}$ ).

After the nutrient deprivation period, six treatments were applied using combinations of two temperatures and three concentrations of nutrients, with 5 replicates per treatment. The experiment per se lasted 10 hours. The factor "Temperature" was represented by $20^{\circ} \mathrm{C}$ and $30^{\circ} \mathrm{C}$, and the factor "Nutrient" was represented by different additions of $\mathrm{NaNO}_{3}{ }^{-}$ and $\mathrm{Na}_{2} \mathrm{HPO}_{4} \cdot 12 \mathrm{H}_{2} \mathrm{O}$ of Von Stosch's enriched seawater (VSE; $500 \mu \mathrm{M} \mathrm{NO}_{3}{ }^{-}$and $30 \mu \mathrm{M} \mathrm{PO}_{4}{ }^{-}$) [31]. The experimental setup values of temperatures are related to the temperature at the upper intertidal fringe at the sampling site, which ranges between $18^{\circ} \mathrm{C}$ (high tide) and $32^{\circ} \mathrm{C}$ (low tide) [29], and the nutrient concentrations were set as $0.1 \mathrm{VSE}, 0.2 \mathrm{VSE}$, and $0.5 \mathrm{VSE}$. These concentrations refer to a gradient of nutrient concentrations that were recorded in Southwestern Atlantic [32, 33]. The treatment set as $0.1 \mathrm{VSE}$ refers to natural eutrophicated waters (upwelling events at collecting site, Arraial do Cabo, Rio de Janeiro) [32], whereas 0.2 VSE and 0.5 VSE refer to the range of nutrient concentrations that were recorded in the human-disturbed Guanabara Bay, Rio de Janeiro [33].

2.4. Fluorescence Measurements. The photosynthetic efficiency of the three species of Ulva in every combination of temperature and nutrient concentration was characterized by chlorophyll- $a$ fluorescence measurements using a submersible diving-PAM ${ }^{\circledR}$ fluorometer (Walz, Effeltrich, Germany). The measurements consisted of recording the effective quantum yield of PSII, which was calculated as $\mathrm{Y}$ $=\left(\mathrm{F}_{\mathrm{m}}^{\prime}-\mathrm{F}_{\mathrm{t}}\right) / \mathrm{F}_{\mathrm{m}}^{\prime}$, where $\mathrm{F}_{\mathrm{m}}^{\prime}$ is the maximum fluorescence in the light (obtained by a saturating actinic light pulse $8900 \mu \mathrm{mol}$ photons $\mathrm{m}^{-2} \mathrm{~s}^{-1} ; 0.8 \mathrm{~s}$ ) and $\mathrm{F}_{\mathrm{t}}$ is the steadystate of fluorescence in the light $[34,35]$. Considering the possibility of physiological differences along the thallus [36], the fluorescence was measured in a similar region of the thallus in each individual.

2.5. Data Analyses. To determine the effects, if any, of temperature and nutrients on these three species of Ulva, based on the Y measurements, a four-way analysis of variance was performed. The analysis included the (i) species (orthogonal, fixed, three levels); (ii) nutrients (orthogonal, fixed, three levels); (iii) temperature (orthogonal, fixed, two levels); and (iv) plot: Erlenmeyer flasks (random and nested in the interaction of factors 1 and 2, two levels). The SNK post hoc test was used to examine the nature of the differences that were detected with ANOVA (0.05 significance level). Statistical analyses were performed using GMAV5 for Windows.

\section{Results}

Differences in the $\mathrm{Y}$ were found for the interaction of species and temperature (Table 1). For both U. lactuca and $U$. rigida, the individuals that were incubated at $30^{\circ} \mathrm{C}$ showed a higher photosynthetic efficiency than did those incubated at $20^{\circ} \mathrm{C}$, whereas no difference in photosynthetic efficiency was 
TABLE 1: Four-way analyses of variance of the photosynthetic capacities (based on the effective quantum yield of the PSII measurements) of three species of Ulva (orthogonal, fixed) that were incubated under different nutrient (orthogonal, fixed, three levels) and temperature (orthogonal, fixed, two levels) conditions. Plot: Erlenmeyer flasks where individuals were incubated (random and nested in the interaction of factors 1 and 2, two levels). SS is sums of squares; DF is degrees freedom; MS is mean of square and P-value $<0.05$.

\begin{tabular}{lccccc}
\hline Source & SS & DF & MS & F \\
\hline Species $(\mathrm{Sp})$ & 0.0003 & 2 & 0.0001 & 0.18 & 0.84 \\
Temperature $(\mathrm{Te})$ & 0.0129 & 1 & 0.0129 & 0.40 & 0.64 \\
Nutrient $(\mathrm{Nu})$ & 0.0018 & 2 & 0.0009 & 2.29 & 0.56 \\
$\mathrm{Plot}(\mathrm{Te} \times \mathrm{Nu})$ & 0.0082 & 6 & 0.0014 & 0.67 & 2.64 \\
$\mathrm{Sp} \times \mathrm{Te}$ & 0.0072 & 2 & 0.0036 & 1.29 & $0.03^{*}$ \\
$\mathrm{Sp} \times \mathrm{Nu}$ & 0.0082 & 4 & 0.0020 & 0.09 \\
$\mathrm{Sp} \times \mathrm{Plot}(\mathrm{Te} \times \mathrm{Nu})$ & 0.0093 & 12 & 0.0008 & 0.23 \\
$\mathrm{Te} \times \mathrm{Nu}$ & 0.0032 & 2 & 0.0016 & 2.63 \\
$\mathrm{Sp} \times \mathrm{Te} \times \mathrm{Nu}$ & 0.0081 & 4 & 0.0020 & 0.38 \\
residual & 0.0861 & 144 & 0.0006 & & \\
total & 0.1452 & 179 & &
\end{tabular}

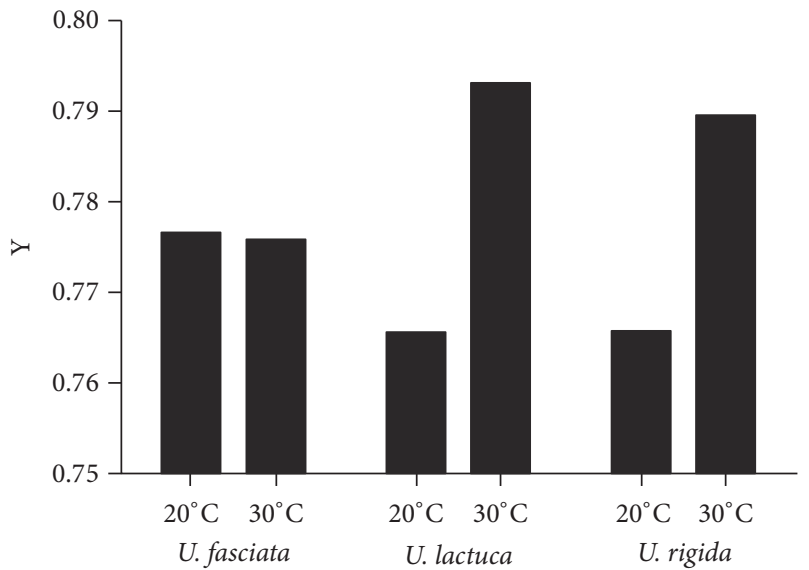

FIgURE 1: Photosynthetic capacities of the three species of Ulva under two temperature conditions (based on the effective quantum yield of PSII measurements). Data from different nutrient conditions and plots (Erlenmeyer flasks where individuals were incubated) were pooled. $\mathrm{n}=30$. Standard deviation values are not shown because of scale-bar limitation (left to right: $0.021,0.023$, $0.032,0.019,0.026$, and 0.035 ).

recorded for $U$. fasciata individuals (Figure 1). Even when an ANOVA was performed for only $U$. fasciata, no difference in photosynthetic efficiency was found.

\section{Discussion}

There are currently 403 species of Ulva in the literature, of which 131 have been flagged as accepted [37]. Even with the development of new tools for taxonomic precision, the identification in the practice may differ from author to author. In this sense, fast and real-time physiological assessment can be helpful to distinguish species and morphotypes of macroalgae.

In this study, two of the three species of Ulva (U. lactuca and $U$. rigida) showed differences in the $\mathrm{Y}$ as related to temperature. Although these species present large morphological distinctions, both showed a higher photosynthetic efficiency at the highest experimental temperature $\left(30^{\circ} \mathrm{C}\right)$, denoting the sensitivity of these species to this temperature value. The physiological differences can be linked to the hydrodynamic environment, once they are under submergence for long periods of time. In this case, this effect of temperature on photosynthetic metabolism is well known for macroalgae [38, 39], and several positive effects on chemical reactions and molecular structures have been reported due to the changes in protein compounds and enzymatic activities [40, 41].

In contrast, Ulva fasciata did not show differences in the photosynthetic efficiency related to the temperature variation. Specifically, this is the most abundant of the three species in the sampling place, dominant at the upper limit of the intertidal zone, as also reported by Guimarães and Coutinho [42]. Its photosynthetic apparatus tolerates changes of at least $10^{\circ} \mathrm{C}$ with no loss of efficiency, as corroborated by our study, which can confer an ecological advantage and seems to support its relative spatial and temporal dominance on rocky shores $[38,43]$.

Despite their unequal abundances, the three species are usually recorded throughout the year, although this cooccurrence is most evident during the summer [29]. The summer period is characterized by high irradiance (i.e., high temperatures on rocky shores), cold waters, and a high input of nutrients from the upwelling and rainfall runoff [44, 45]. Taken together, these results suggest that the ecophysiological differences that were pointed in this study provide a reasonable explanation for the variability in the spatial and temporal abundance of these species of Ulva on rocky shores.

It is important to highlight that despite the absence of nutrient effects on the photosynthetic response of Ulva species in our study, we are not fully disregarding the importance of this factor as a driver of the spatial and temporal variability of Ulva species on rocky shores. Nutrient enrichment favors ephemeral foliose macroalgae (see [3]) by increasing the photosynthetic response [46]. In fact, the 
genus Ulva is recognized by the affinity for nitrogen [4749], and differences in photosynthetic efficiency have been predicted (if not among species, at least among nutrient concentrations), in contrast to the present results. Considering the proper experimental design and applied manipulative measurements, we attribute these findings to a saturated rate of nutrient availability: light supply in our experiment.

One of the most vexing taxonomic concerns refers to the $U$. fasciata and U. lactuca species, which cooccur with $U$. rigida. Regarding U. fasciata and U. lactuca, there is a longstanding taxonomic debate (see $[1,10-13,50,51])$. Meanwhile, several studies confirm $U$. rigida as a consistent valid species [52-54]. We corroborate the previous claim of Hiraoka et al. [10], Shimada et al. [50], and Kirkendale et al. [1]. Our study considered ecophysiological and morphological (based on [28-30]) data for specimens from Southwestern Atlantic. Therefore, we propose the use of ecophysiology as a complementary tool for taxonomic distinction among macroalgae based on chlorophyll- $a$ fluorescence to enlighten this debate with additional taxonomic evidence. Similar morphophysiological studies, based on classic morphometry and photosynthetic responses (maximum electron transport rates, ETRmax), suggested different species of Durvillaea (Phaeophyceae) for two morphotypes cooccurring in southern Chile [26].

However, how this ecophysiology method would respond on other marine macroalgal taxa remains to be tested. We understand that it is hard to apply the methodology to identification of freshly collected specimens or species in the field without further investigation, either by morphology or molecular methods. We also recognize the undeniable contribution of morphology and molecular methods to taxonomy, and our proposal aims to enlighten the debate with additional evidence.

\section{Data Availability}

The data used to support the findings of this study are available from the corresponding author upon request.

\section{Conflicts of Interest}

The authors declare that they have no conflicts of interest.

\section{Acknowledgments}

We are in debt to Mariana Mayer Pinto for her support with the GMAV5 program. We also thank the Conselho Nacional de Desenvolvimento Científico e Tecnológico (CNPq), Coordenação de Aperfeiçoamento de Pessoal de Nível Superior (CAPES), and Fundação de Amparo à Pesquisa do Estado do Rio de Janeiro (FAPERJ) for financial support and scholarships to AEP, VPO, and NTM.

\section{References}

[1] L. Kirkendale, G. W. Saunders, and P. Winberg, "A molecular survey of ulva (chlorophyta) in temperate australia reveals enhanced levels of cosmopolitanism," Journal of Phycology, vol. 49, no. 1, pp. 69-81, 2013.

[2] R. S. Steneck and M. N. Dethier, "A functional group approach to the structure of algal-dominated communities," Oikos, vol. 69, no. 3, pp. 476-498, 1994.

[3] R. L. Fletcher, "The occurrence of "green tides"- a review," in Marine Benthic Vegetation: Recent Changes and The Effects of Eutrophication, vol. 123 of Ecological Studies, pp. 7-43, Springer Berlin Heidelberg, Berlin, Germany, 1996.

[4] T. A. Nelson, K. Haberlin, A. V. Nelson et al., "Ecological and physiological controls of species composition in green macroalgal blooms," Ecology, vol. 89, no. 5, pp. 1287-1298, 2008.

[5] M. Teichberg, S. E. Fox, Y. S. Olsen et al., "Eutrophication and macroalgal blooms in temperate and tropical coastal waters: nutrient enrichment experiments with Ulva spp," Global Change Biology, vol. 16, no. 9, pp. 2624-2637, 2010.

[6] R. Paulert, V. Talamini, J. E. F. Cassolato, M. E. R. Duarte, M. D. Noseda, and M. J. Stadnik, "Effects of sulfated polysaccharide and alcoholic extracts from green seaweed Ulva fasciata on anthracnose severity and growth of common bean (Phaseolus vulgaris L.)," Journal of Plant Diseases and Protection, vol. 116, no. 6, pp. 263-270, 2009.

[7] M. Lenzi, G. Salvaterra, P. Gennaro et al., "A new approach to macroalgal bloom control in eutrophic, shallow-water, coastal areas," Journal of Environmental Management, vol. 150, pp. 456e-465e, 2015.

[8] Z. Gao, D. Xu, C. Meng et al., "The green tide-forming macroalga Ulva linza outcompetes the red macroalga Gracilaria lemaneiformis via allelopathy and fast nutrients uptake," Aquatic Ecology, vol. 48, no. 1, pp. 53-62, 2014.

[9] H. Verbruggen, "Morphological complexity, plasticity, and species diagnosability in the application of old species names in DNA-based taxonomies," Algae Highlights, vol. 50, no. 1, pp. 26-31, 2013.

[10] M. Hiraoka, S. Shimada, Y. Serisawa, M. Ohno, and H. Ebata, "Two different genetic strains of stalked-Ulva (Ulvales, Chlorophyta) grow on intertidal rocky shores in Ebisujima, central Japan," Phycological Research, vol. 51, no. 3, pp. 161-167, 2003.

[11] D. Butler, "Ancient algal mixup sorted," Nature, 2007.

[12] L. G. K. Kraft, G. T. Kraft, and R. F. Waller, "Investigations into southern Australian ulva (ulvophyceae, chlorophyta) taxonomy and molecular phylogeny indicate both cosmopolitanism and endemic cryptic species," Journal of Phycology, vol. 46, no. 6, pp. 1257-1277, 2010.

[13] C. J. O'Kelly, A. Kurihara, T. C. Shipley, and A. R. Sherwood, "Molecular assessment of ulva spp. (ulvophyceae, chlorophyta) in the hawaiian islands," Journal of Phycology, vol. 46, no. 4, pp. 728-735, 2010.

[14] N. Knowlton, "Sibling species in the sea," Annual Review of Ecology, Evolution and Systematics, vol. 24, no. 1, pp. 189-216, 1993.

[15] P. D. N. Hebert, A. Cywinska, S. L. Ball, and J. R. DeWaard, "Biological identifications through DNA barcodes," Proceedings of the Royal Society B Biological Science, vol. 270, no. 1512, pp. 313-321, 2003.

[16] N. Puillandre, P. Bouchet, M. C. Boisselier-Dubayle et al., "New taxonomy and old collections: Integrating DNA barcoding into the collection curation process," Molecular Ecology Resources, vol. 12, no. 3, pp. 396-402, 2012.

[17] G. Du, F. Wu, Y. Mao, S. Guo, H. Xue, and G. Bi, "DNA barcoding assessment of green macroalgae in coastal zone 
around Qingdao, China," Journal of Ocean University of China, vol. 13, no. 1, pp. 97-103, 2014.

[18] W. L. Bauerle, D. J. Weston, J. D. Bowden, J. B. Dudley, and J. E. Toler, "Leaf absorptance of photosynthetically active radiation in relation to chlorophyll meter estimates among woody plant species," Scientia Horticulturae (Amsterdam), vol. 101, no. 1-2, pp. 169-178, 2004.

[19] N. R. Baker, "Chlorophyll fluorescence: a probe of photosynthesis in vivo," Annual Review of Plant Biology, vol. 59, pp. 89-113, 2008.

[20] U. Schreiber, W. Bilger, and C. Neubauer, "Chlorophyll fluorescence as a nonintrusive indicator for rapid assessment of in vivo photosynthesis," Ecological Studies, vol. 100, pp. 49-70, 1994.

[21] A. Espinosa-Calderon, I. Torres-Pacheco, J. A. Padilla-Medina et al., "Description of photosynthesis measurement methods in green plants involving optical techniques, advantages and limitations," African Journal of Agricultural Research, vol. 6, no. 12, pp. 2638-2647, 2011.

[22] T. P. J. Krüger, C. Ilioaia, and R. Van Grondelle, "Fluorescence intermittency from the main plant light-harvesting complex: Resolving shifts between intensity levels," The Journal of Physical Chemistry B, vol. 115, no. 18, pp. 5071-5082, 2011.

[23] A. A. Fernandez-Jaramillo, C. Duarte-Galvan, L. M. ContrerasMedina et al., "Instrumentation in developing chlorophyll fluorescence biosensing: a review," Sensors (Switzerland), vol. 12, no. 9, pp. 11853-11869, 2012.

[24] V. P. Oliveira, N. T. Martins, Y. Yoneshigue-Valentin, and A. Enrich-Prast, "Chlorophyll-a fluorescence in ecology: theoretical considerations and examples around marine macroalgae," Journal of Environmental Science and Engineering, vol. A22, pp. 1165-1172, 2013.

[25] K. Maxwell and G. N. Johnson, "Chlorophyll fluorescence-a practical guide," Journal of Experimental Botany, vol. 51, no. 345, pp. 659-668, 2000.

[26] F. Méndez, F. Tala, R. Rautenberger et al., "Morphological and physiological differences between two morphotypes of durvillaea antarctica (phaeophyceae) from the sub-antarctic ecoregion of magallanes, chile," Journal of Applied Phycology, vol. 29 , no. 5, pp. 2557-2565, 2017.

[27] W. R. Taylor, Marine algae of the eastern tropical and subtropical coasts of the Americas, The University of Michigan Press, Michigan, Mich, USA, 1960.

[28] A. B. Joly, "Flora marinha do litoral norte do estado de são paulo e regiões circunvizinhas," in Boletim da Faculdade de Filosofia, Ciências e Letras da Universidade de São Paulo, vol. 249, pp. 5393, Departamento de Botânica da USP, Universidade de São Paulo, 1965.

[29] Y. Yoneshigue, Taxonomie et écologie des algues marines dans la région de cabo frio (rio de janeiro, brésil)[Ph.D. thesis], Université d’Aix-Marseille II, Marseille, France, 1985.

[30] Y. Yoneshigue-Valentin and J. L. Valentin, "Macroalgae of the cabo frio upwelling region, brazil: ordination of communities," in Coastal plant communities of Latin America, U. Seeliger, Ed., Academic Press, San Diego, Calif, USA, 1992.

[31] H. Von Stosch, Wirkungen von Jod und Arsenit auf Meeresalgen in Kultur, vol. 4 of Proc. Inter. Seaw. Symp., 1963.

[32] J. L. Valentin, D. L. Andre, and S. A. Jacob, "Hydrobiology in the cabo frio (Brazil) upwelling: two-dimensional structure and variability during a wind cycle," Continental Shelf Research, vol. 7, no. 1, pp. 77-88, 1987.
[33] B. Kjerfve, C. H. A. Ribeiro, G. T. M. Dias, A. M. Filippo, and V. D. S. Quaresma, "Oceanographic characteristics of an impacted coastal bay: baía de guanabara, rio de janeiro, Brazil," Continental Shelf Research, vol. 17, no. 13, pp. 1609-1643, 1997.

[34] B. Genty, J. M. Briantais, and N. R. Baker, "The relationship between the quantum yield of photosynthetic electron transport and quenching of chlorophyll fluorescence," Biochimica et Biophysica Acta (BBA) - General Subjects, vol. 990, pp. 87-92, 1989.

[35] J. C. Kromkamp and R. M. Forster, "The use of variable fluorescence measurements in aquatic ecosystems: differences between multiple and single turnover measuring protocols and suggested terminology," European Journal of Phycology, vol. 38, no. 2, pp. 103-112, 2003.

[36] W. Han, X. W. Xu, L. Li, J. Q. Lei, and S. Y. Li, "Chlorophyll a fluorescence responses of Haloxylon ammodendron seedlings subjected to progressive saline stress in the Tarim desert highway ecological shelterbelt," Photosynthetica, vol. 48, no. 4, pp. 635-640, 2010.

[37] M. D. Guiry and G. M. Guiry, Algae Base, Galway, Ireland, Worldwide electronic publication: National University of Ireland, 2018, http://www.algaebase.org.

[38] I. R. Davison, "Environmental effects on algal photosynthesis: temperature," Journal of Phycology, vol. 27, no. 1, pp. 2-8, 1991.

[39] Y. Wang, Y. Wang, L. Zhu, B. Zhou, X. Tang, and B. Neilan, "Comparative studies on the ecophysiological differences of two green tide macroalgae under controlled laboratory conditions," PLoS ONE, vol. 7, no. 8, Article ID e38245, 2012.

[40] J. A. Raven and R. J. Geider, "Temperature and algal growth," New Phytologist, vol. 110, no. 4, pp. 441-461, 1988.

[41] L. C. Rai and J. P. Gaur, Algal Adaptation to Environmental Stresses: Physiological, Biochemical and Molecular Mechanisms, Springer Berlin Heidelberg, Berlin, Germany, 2001.

[42] M. A. De Guimarães and R. Coutinho, "Spatial and temporal variation of benthic marine algae at the cabo frio upwelling region, rio de janeiro, Brazil," Aquatic Botany, vol. 52, no. 4, pp. 283-299, 1996.

[43] I. R. Davison and G. A. Pearson, "Stress tolerance in intertidal seaweeds," Journal of Phycology, vol. 32, no. 2, pp. 197-211, 1996.

[44] J. L. Valentin, "Analyse des paramètres hydrobiologiques dans la remontée de cabo frio (Brésil)," Marine Biology, vol. 82, no. 3, pp. 259-276, 1984.

[45] G. C. Pereira, R. Coutinho, and N. F. F. Ebecken, "Data mining for environmental analysis and diagnostic: a case study of upwelling ecosystem of arraial do cabo," Brazilian Journal of Oceanography, vol. 56, no. 1, pp. 1-12, 2008.

[46] P. G. Falkowski and J. A. Raven, Aquatic Photosynthesis, Princeton University Press, New Jersey, NJ, USA, 2007.

[47] Y. B. Ho, "Ulva lactuca (Chlorophyta, Ulvales) in Hong Kong intertidal waters - its nitrogen and phosphorus contents and its use as a bioindicator of eutrophication," in Asian Marine Biology, vol. 4, pp. 97-102, 1987.

[48] I. DÍez, A. Secilla, A. Santolaria, and J. M. Gorostiaga, "Phytobenthic intertidal community structure along an environmental pollution gradient," Marine Pollution Bulletin, vol. 38, no. 6, pp. 463-472, 1999.

[49] B. Worm and H. K. Lotze, "Effects of eutrophication, grazing, and algal blooms on rocky shores," Limnology and Oceanography, vol. 51, no. 1, pp. 569-579, 2006.

[50] S. Shimada, M. Hiraoka, S. Nabata, M. Iima, and M. Masuda, "Molecular phylogenetic analyses of the Japanese Ulva and 
Enteromorpha (Ulvales, Ulvophyceae), with special reference to the free-floating Ulva," Phycological Research, vol. 51, no. 2, pp. 99-108, 2003.

[51] M. Cormaci, G. Furnari, and G. Alongi, "Marine benthic flora of the Mediterranean sea: chlorophyta," Bollettino delle sedute della Accademia Gioenia di Scienze Naturali in Catania, vol. 377, pp. 11-436, 2014.

[52] K. Kostamo, J. Blomster, H. Korpelainen et al., "New microsatellite markers for ulva intestinalis (chlorophyta) and the transferability of markers across species of ulvaceae," Phycologia, vol. 47, no. 6, pp. 580-587, 2008.

[53] C. J. Loughnane, L. M. McIvor, F. Rindi, D. B. Stengel, and M. D. Guiry, "Morphology, rbcL phylogeny and distribution of distromatic Ulva (Ulvophyceae, Chlorophyta) in Ireland and southern Britain," Phycologia, vol. 47, no. 4, pp. 416-429, 2008.

[54] L. C. Hofmann, J. C. Nettleton, C. D. Neefus, and A. C. Mathieson, "Cryptic diversity of Ulva (Ulvales, Chlorophyta) in the great bay Estuarine system (Atlantic USA): introduced and indigenous distromatic species," European Journal of Phycology, vol. 45, no. 3, pp. 230-239, 2010. 


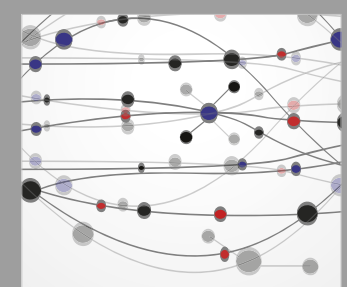

The Scientific World Journal
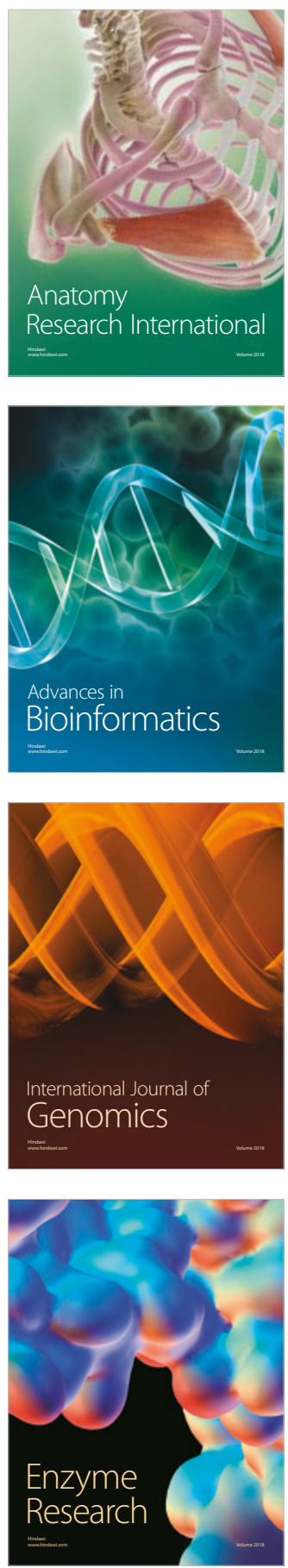
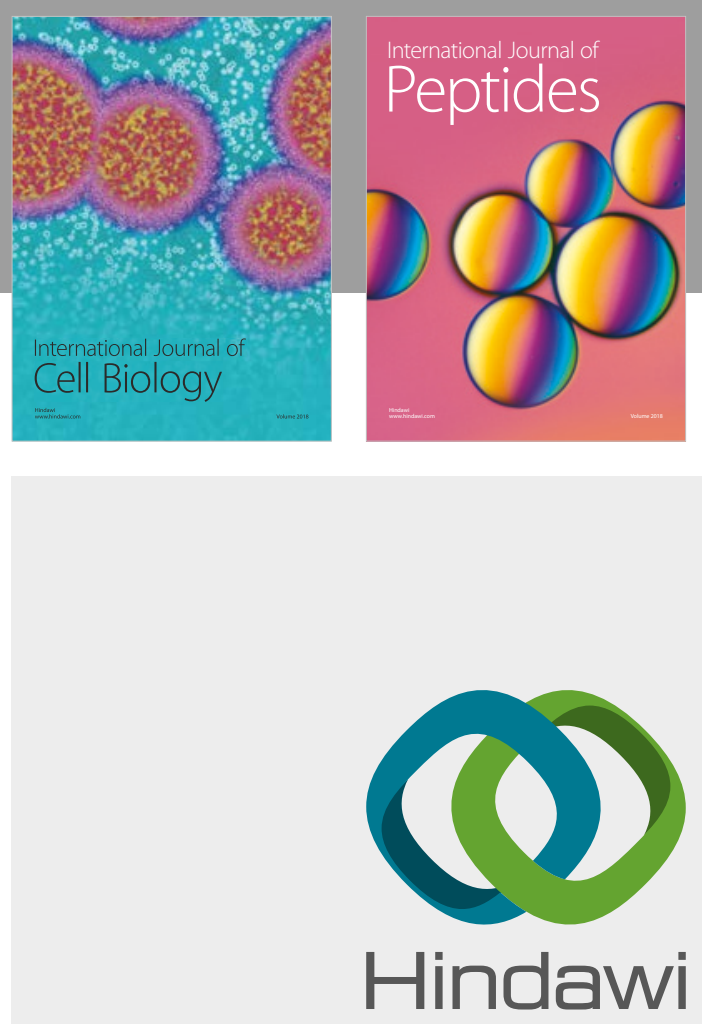

Submit your manuscripts at

www.hindawi.com
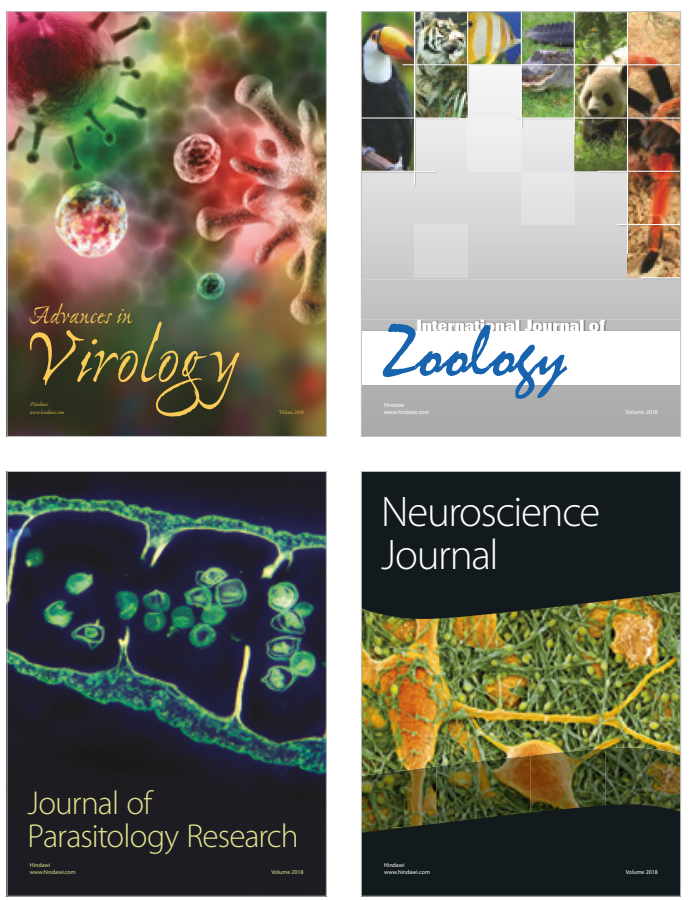
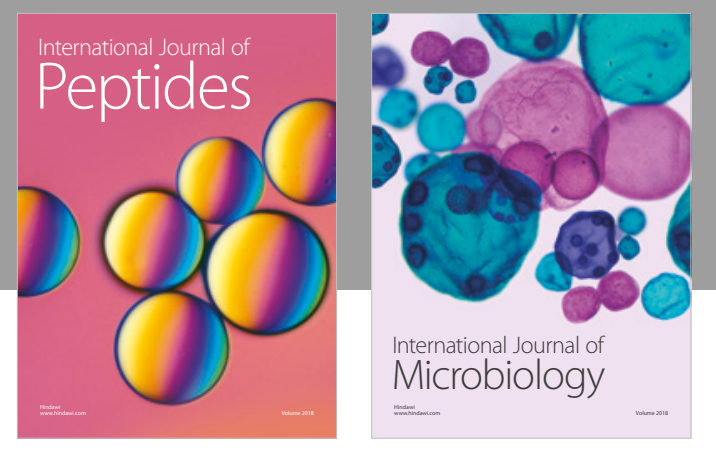

nternational Journal of Microbiology
Journal of
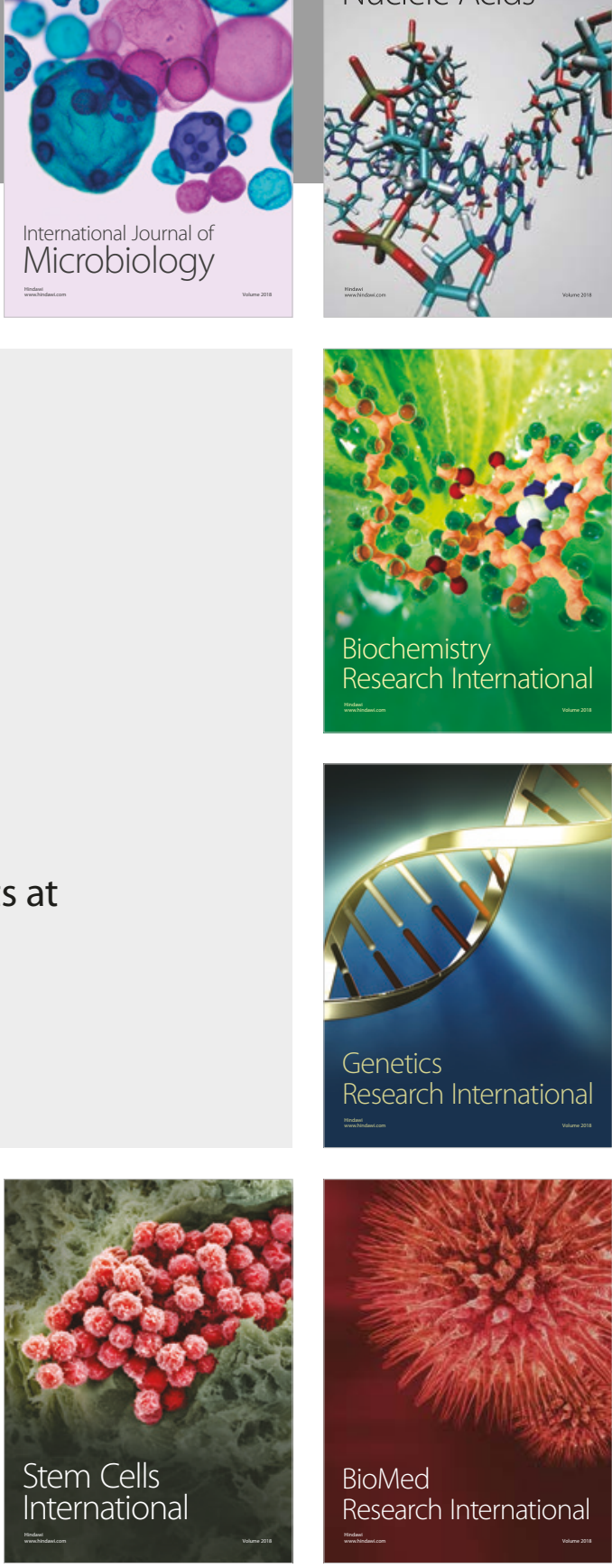
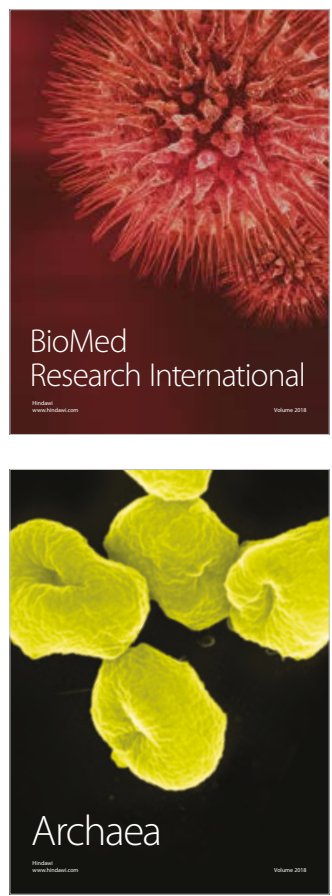